\title{
Titanium alloy miniscrews for orthodontic anchorage: an in vivo study of metal ion release
}

\section{Miniimplantes de liga de titânio para ancoragem ortodôntica: um estudo in vivo de liberação de íon metálico}

\section{Abstract}

Purpose: To examine and compare the levels of several metal ions released in the saliva of patients with orthodontic appliances, at different time points before and after insertion of a miniscrew.

Methods: Saliva of patients $(n=20)$ was collected at four time points: before miniscrew placement (T1), 10 minutes (T2), 7 days (T3) and 30 days after miniscrew placement (T4). The salivary samples were analyzed by inductively coupled plasma mass spectrometry (ICP-MS) and inductively coupled plasma optical emission spectrometry (ICP-OES). The release of nine different metal ions was observed: titanium (Ti), zinc $(\mathrm{Zn})$, chromium $(\mathrm{Cr})$, nickel $(\mathrm{Ni})$, iron $(\mathrm{Fe})$, copper (Cu), aluminum (Al), Vanadium (V) and cobalt (Co). Data were analyzed by descriptive statistics. Salivary metal concentrations from different time points of miniscrew treatment were compared using Wilcoxon paired tests $(\alpha=5 \%)$.

Results: At time point T4, there was a quantitative increase in the salivary concentration of $\mathrm{Cu}$, $\mathrm{Ti}, \mathrm{V}, \mathrm{Zn}$, as well as a quantitative decrease in the salivary concentration of $\mathrm{Al}, \mathrm{Co}, \mathrm{Cr}, \mathrm{Fe}, \mathrm{Ni}$, when compared with $T 1$.

Conclusion: It can be concluded that the placement of fixed orthodontic appliances associated with miniscrews does not lead to an increase of salivary metal ion concentrations.

Key words: Metal ions; miniscrews; ICP-MS; ICP-OES; orthodontic appliances

\section{Resumo}

Objetivo: Examinar e comparar os níveis de diferentes íons metálicos liberados na saliva de pacientes com aparelhos ortodônticos, em diferentes tempos: antes e após a inserção de mini-implantes.

Metodologia: A saliva de pacientes $(n=20)$ foi coletada em quatro tempos diferentes: antes da inserção do mini-implante (T1), 10 minutos (T2), 7 dias (T3) e 30 dias após a remoção do mini-implante (T4). As amostras de saliva foram analisadas por espectrometria de massa de plasma com acoplamento por indução (ICP-MS) e espectrometria de emissão ótica por plasma acoplado indutivamente (ICP-OES). A liberação de nove diferentes ions metálicos foi observado: titânio $(\mathrm{Ti})$, zinco $(\mathrm{Zn})$, cromo $(\mathrm{Cr})$, níquel $(\mathrm{Ni})$, ferro $(\mathrm{Fe})$, cobre $(\mathrm{Cu})$, alumínio (Al), vanádio(V) e cobalto (Co).Os dados foram analisados por estatística descritiva. As concentrações de íons metálicos na saliva dos diferentes tempos estudados foram comparados através do teste pareado de Wilcoxon $(\alpha=5 \%)$.

Resultados: No tempo T4, houve um aumento quantitativo na concentração salivar de $\mathrm{Cu}$, $\mathrm{Ti}, \mathrm{V}, \mathrm{Zn}$, assim como um decréscimo quantitativo na concentração salivar de $\mathrm{Al}, \mathrm{Co}, \mathrm{Cr}, \mathrm{Fe}$, $\mathrm{Ni}$, quando comparados com $\mathrm{Tl}$.

Conclusão: Pode ser concluído que a colocação de aparelho fixo ortodôntico associado com mini-implantes não leva a um aumento significativo na concentração salivar de íons metálicos.

Palavras-chave: Íons metálicos; mini-implantes; ICP-MS; ICP-OES; aparelhos ortodônticos

\author{
Micéli Guimarães Blaya a \\ Diego Segatto Blaya ${ }^{\circ}$ \\ Paola Mello b \\ Érico M. M. Flores b \\ Luciana M. Hirakata a
}

- School of Dentistry, Pontifical Catholic University of Rio Grande do Sul, Porto Alegre, RS, Brazil

${ }^{b}$ Chemistry Department, Federal University of Santa Maria, Santa Maria, RS, Brazil

\author{
Correspondence: \\ Micéli Guimarães Blaya \\ Av. Ipiranga, 6681 - Building 6 \\ Porto Alegre, RS - Brazi \\ 90619-900 \\ E-mail:miceliblaya@gmail.com
}

Received: May 25, 2011

Accepted: August 29, 2011

Conflict of Interest Statement: The authors state that there are no financial and personal conflicts of interest that could have inappropriately influenced their work.

Copyright: (C) 2011 Blaya et al.; licensee EDIPUCRS. This is an Open Access article distributed under the terms of the Creative Commons AttributionNoncommercial-No Derivative Works 3.0 Unported License. 


\section{Introduction}

Ti $-6 \mathrm{~A}-4 \mathrm{~V}$ is the most frequently used titanium alloy for medical implants and orthodontic miniscrews because of its excellent properties $(1,2)$. However, several studies suggested the cytotoxicity and dissolution of this alloy (2-4) and its corrosion products (5-8). In addition, the concentrations of these metals have been measured in the blood, urine and tissues (9).

In the alloy Ti-6Al-4V, superficial oxide is composed of $\mathrm{TiO}_{2}$, with small amounts of $\mathrm{Al}_{2} \mathrm{O}_{3}$, hydroxylic groups and water (10). Its superficial oxide layer is less stable than that of commercially pure Ti because the $\mathrm{Al}$ and $\mathrm{V}$, which are added to stabilize the $\alpha$ and $\beta$ phases, respectively, desestabilize the alloy, making it more vulnerable to corrosion (11). As $\mathrm{V}$ is not present in the superficial oxide layer of Ti-6Al-4V (10), Ti and Al are the metal ions most likely to be released from the Ti-6Al-4V surface(12).

According to Hanawa (10), the most harmful components of metallic implants are Co from $\mathrm{Cr}-\mathrm{Co}$ alloy, $\mathrm{Ni}$ from stainless steel and V from Ti-6Al-4V alloy. However, both V and $\mathrm{Al}$ in Ti-6Al-4V are potentially toxic $(13,14)$. The $\mathrm{Al}$ ions affect the proliferation, metabolic activity and differentiation of osteoblasts (12). Some toxic effects attributed to $\mathrm{Al}$ accumulation in the human body have been described in the literature (encephalopathia and senile dementia of the Alzheimer's type) (15). The element may also be associated with osteomalacia and pulmonary granulomatosis (14).

Vanadium is an essential element for the functioning of our organism (16). However, toxic vanadium may elicit local or especially systemic reactions or inhibit cellular proliferation. Vanadium may be cytotoxic for alveolar macrophages and synovial fibroblasts, interferes with mitosis and chromosome distribution and therefore presents a real risk of carcinogenicity $(16,17)$. Titanium ions may induce a decrease in the number and activity of osteoblasts, macrophages and leukocytes (12), hampering osteogenesis.

The oral environment is ideal for the biodegradation of metals due to its thermal, microbiological and enzymatic properties (18). Thus, it is uncertain whether these alloys, which are used in miniscrews, produce corrosion debris as a result of wear and whether the debris is cytotoxic to bone (9). It is well known that metals released from orthodontic appliances, metal restorations and metal prostheses can cause potentially toxic effects on tissues, but it is unknown whether metals released from miniscrews used as orthodontic anchorage are potentially toxic.

Therefore, the aim of the present study was to examine and compare the levels of several metal ions released in the saliva of patients with orthodontic appliances and with miniscrews as orthodontic anchorage.

\section{Methods}

This study was approved by The Committee of Ethics and Research of the Pontifical Catholic University of Rio Grande do Sul (PUCRS/ Brazil), in accordance with national and international norms of research in human beings (registration number $=09 / 04788)$.

\section{Sample}

A total of 20 patients (12 females and 8 males) were included in the study. The mean age of the sample was 21.4 years old (range: 16 to 32 years old) and these patients were selected from a private clinic. None of the patients were smokers, had pre-existing systemic diseases or were under any pharmacological treatment.

All patients were treated by the same orthodontist (M.B.) and were within the $6^{\text {th }}$ and $8^{\text {th }}$ month of treatment. The fixed orthodontic appliance consisted of: 8 bands and 20 bonded brackets. None of the patients had palatal or lingual appliances weIded to the bands or any extraoral orthodontic appliances. None of the patients had any amalgam fillings or metallic restorations.

A preadjusted straight-wire appliance was used in all cases (10.10.971 reference, special roth brackets set with hook on the canines and premolars $0,56 \times 0,76 \mathrm{~mm}$-Morelli, Sorocaba, SP, Brazil). Both the permanent maxillary and mandibular molars were banded (Morelli, Sorocaba, SP, Brazil). First maxillary molar bands had triple buccal tubes with hooks, whereas first mandibular molar bands had double bucal tubes with hooks. Second maxillary and mandibular molar bands had single buccal tubes. Metallic brackets were directly bonded on incisors, canines, and premolars. A 0.018-inch or 0.020 -inch stainless steel archwire was placed on both arches (Morelli, Sorocaba/SP, Brazil) and tied with elastics (Morelli, Sorocaba, SP, Brazil).

All patients were classified as class II malocclusion with left or right subdivision, that is, they possessed malocclusion Class I on one side and class II on the counter-lateral side. These patients, therefore, needed correction for superior arch asymmetry, which was achieved through molar distalization with the use of a miniscrew as orthodontic anchorage in the superior arch, placed interdentally between the roots of the superior first and second pre-molars. The miniscrews were placed by the same oral and maxillofacial surgeon (D.B.) with the same surgical technique.

All miniscrews remained stable as an anchorage unit for the appliance during the orthodontic treatment. Before the treatment, all patients gave signed informed consent (in accordance with bioethics norms) to the treatment plan, which consisted of implantation of one miniscrew in the superior arch. Those patients that chose not to accept the treatment with miniscrew were excluded from the study without any disruption to their treatment.

\section{Mini-screw installation}

A surgical guide made of orthodontic wire was used in all patients to verify the receptor site. Periapical radiographs were made before miniscrew implantation, in order to verify the miniscrew site without damaging the teeth or anatomic structures.

Miniscrews were installed under local anesthesia of the soft tissues at the implant receptor site. The entire procedure 
was carried out under sterile conditions. The miniscrew was inserted with a manual handpiece screwdriver (Sin Implant Systems, São Paulo, SP, Brazil) and considered immobile and stable at the moment of placement. Self-tapping miniscrews with a total length of $10 \mathrm{~mm}$, screw head of $3 \mathrm{~mm}$ and 1.2 $\mathrm{mm}$ of diameter were obtained from Sin Implant Systems (Sin Implant Systems, São Paulo, SP, Brazil).

After installation, a periapical radiograph was taken to evaluate the position of the miniscrew. After the surgical procedure, oral hygiene with an extra-soft toothbrush and the use of a $0.12 \%$ chlorhexidine mouth rinse were prescribed. No other medications were prescribed. The miniscrews were used in the maxilla and were loaded two weeks after placement.

\section{Collection and processing of saliva}

Samples of stimulated saliva were collected by the following method: the patient thoroughly rinsed the mouth with deionized water for 1 minute (Dermapelle, Santa Maria, RS, Brazil). Next, the patient spit non-stimulated salivary secretion at different time points (Table 1). Approximately $10 \mathrm{~mL}$ of saliva were collected into a sterile glass tube. After collection, the samples were stored at $-20^{\circ} \mathrm{C}$ in a freezer.

Table 1. Time points of saliva collection.

\begin{tabular}{lc}
\hline Group & Time of saliva collection \\
\hline Immediately before miniscrew insertion & Immediately before $-\mathrm{T} 1$ \\
After miniscrew insertion & 10 minutes $-\mathrm{T} 2$ \\
& 7 days $-\mathrm{T} 3$ \\
& 30 days $-\mathrm{T} 4$ \\
\hline
\end{tabular}

For metal determinations, saliva samples $(1 \mathrm{~mL})$ were digested in a hot water bath $\left(80^{\circ} \mathrm{C}, 1\right.$ hour $)$ with $1 \mathrm{~mL}$ of $14 \mathrm{~mol} \mathrm{~L}^{-1}$ nitric acid (Merck, Darmstadt, Germany) and $0.5 \mathrm{~mL}$ of $30 \%(\mathrm{v} / \mathrm{v})$ hydrogen peroxide (Synth, Diadema, SP, Brazil) in polypropylene tubes (Sarstedt, Nümbrecht, Germany). After digestion, samples were diluted to $5 \mathrm{~mL}$ with ultra pure water and centrifuged (Nova Técnica, Piracicaba, SP, Brazil) at 3,000 rpm for 4 minutes prior to analysis.

\section{Estimation of metal ions released}

Metal content in digested saliva samples was determined by inductively coupled plasma mass spectrometry (ICP-MS) and inductively coupled plasma optical emission spectrometry (ICP-OES). Co, Cr, Ni, and V were determined by ICP-MS using an inductively coupled plasma mass spectrometer (PerkinElmer-SCIEX, model Elan DRC II, Thornhill, Canada), equipped with a concentric nebulizer, a cyclonic spray chamber and a quartz torch with a quartz injector tube ( $2 \mathrm{~mm}$ i.d.). Instrumental performance optimization, including nebulizer gas flow rate, ion lens voltage, and torch alignment, was carried out according to manufacturer instructions (Perkin-Elmer-Sciex, Elan version 3.0, Software guide, 1006920 A, 2003, Thornhill, Canada). The operational conditions are shown in Table 2. An inductively coupled plasma optical emission spectrometer (ICP-OES - Spectro Ciros CCD, Spectro Analytical Instruments, Kleve, Germany with an axial view configuration) was used for $\mathrm{Al}, \mathrm{Zn}, \mathrm{Cu}$, $\mathrm{Fe}$ and $\mathrm{Ti}$ determinations. Nebulization was performed through a crossflow nebulizer coupled to a Scott double pass type nebulization chamber. Plasma operating conditions and selected wavelengths used for metal determinations are listed in Table 2, and they were used as recommended by the instrument manufacturer (Spectro Ciros CCD, Software version 01/March 2003, Spectro Analytical Instruments, Kleve, Germany). For ICP-MS and ICP-OES determinations, argon 99.996\% (White Martins-Praxair, Sao Paulo, Brazil) was used for plasma generation, for nebulization, and as the auxiliary gas.

Table 2. Operational Parameters metals determinations by ICP-OES and ICP-MS.

\begin{tabular}{|c|c|c|}
\hline Parameter & ICP-OES & ICP-MS \\
\hline Rf power (W) & 1650 & 1400 \\
\hline Plasma gas flow rate (L min- 1 ) & 12.0 & 15.0 \\
\hline Auxiliary gas flow rate (L min-1) & 1.0 & 1.2 \\
\hline Nebulizer gas flow rate (L min-1) & 1.0 & 1.15 \\
\hline Spray chamber & $\begin{array}{c}\text { double pass, } \\
\text { Scott type }\end{array}$ & cyclonic \\
\hline Nebulizer & crossflow & concentric \\
\hline View & axial & \\
\hline Sampler and skimmer cones & & $\mathrm{Pt}$ \\
\hline Ion lens (V) & & 7.2 \\
\hline Dwell time (ms) & & 50 \\
\hline Isotope $(\mathrm{m} / \mathrm{z})$ & & $\begin{array}{l}{ }^{109} \mathrm{Ag} \\
{ }^{59} \mathrm{Co} \\
{ }^{53} \mathrm{Cr} \\
{ }^{60} \mathrm{Ni} \\
{ }^{51} \mathrm{~V}\end{array}$ \\
\hline Wavelength (nm) & $\begin{array}{l}396.153 \mathrm{Al} \\
327.393(\mathrm{Cu}) \\
259.939(\mathrm{Fe}) \\
334.490(\mathrm{Ti}) \\
213.857(\mathrm{Zn})\end{array}$ & \\
\hline
\end{tabular}

Statistical analysis

Data were analyzed with descriptive statistics and normality test (Shapiro-Wilk). Comparisons of salivary element concentrations among different times of miniimplant treatment were analyzed by Wilcoxon paired tests ( $\alpha=5 \%$ ). The software Statistical Package for Social Sciences (SPSS, Chicago, Illinois, USA) was used to perform the statistical analysis.

\section{Results}

Results from the analysis of the concentration of $\mathrm{Al}, \mathrm{Ti}$, $\mathrm{Cr}, \mathrm{Ni}, \mathrm{Fe}, \mathrm{Cu}, \mathrm{Co}, \mathrm{Zn}$ and $\mathrm{V}$ ions released at different times of miniscrew treatment are shown in Table 3. 
Table 3. Comparison among the metal ion concentrations in salivary samples among different time points ( $\mu \mathrm{g} / \mathrm{L})$.

\begin{tabular}{|c|c|c|c|c|c|c|c|c|}
\hline \multirow{2}{*}{ Element } & \multicolumn{2}{|c|}{$\begin{array}{l}\text { before placement } \\
\text { of miniscrew }\end{array}$} & \multicolumn{2}{|c|}{$\begin{array}{c}10 \text { minutes after insertion } \\
\text { of miniscrew }\end{array}$} & \multicolumn{2}{|c|}{$\begin{array}{l}7 \text { days after insertion } \\
\text { of miniscrew }\end{array}$} & \multicolumn{2}{|c|}{$\begin{array}{c}30 \text { days after insertion } \\
\text { of miniscrew }\end{array}$} \\
\hline & Mean & $\mathrm{Sd}$ & Mean & $\mathrm{Sd}$ & Mean & $\mathrm{Sd}$ & Mean & $\mathrm{Sd}$ \\
\hline (Al) & 127.8 & 95.0 & 101.9 & 60.6 & 240.0 & 450.4 & 123.6 & 58.5 \\
\hline (Co) & 0.6 & 0.4 & 0.5 & 0.1 & 2.3 & 5.6 & 0.5 & 0.3 \\
\hline$(\mathrm{Cr})$ & 7.1 & 6.2 & 7.2 & 6.2 & 7.4 & 6.3 & 7.0 & 6.2 \\
\hline (Cu) & 78.0 & 67.9 & 54.2 & 33.7 & 87.3 & 142.2 & 100.2 & 73.0 \\
\hline$(\mathrm{Fe})$ & 272.5 & 138.3 & 368.3 & 193.7 & 261.5 & 170.1 & 260.3 & 111.1 \\
\hline$(\mathrm{Ni})$ & 7.1 & 2.7 & 6.9 & 2.3 & 6.69 & 2.69 & 6.5 & 3.8 \\
\hline ( $\mathrm{Ti})$ & 35.3 & 22.8 & 39.9 & 59.6 & 52.6 & 53.8 & 104.3 & 123.0 \\
\hline$(V)$ & 2.2 & 0.7 & 2.4 & 1.1 & 3.4 & 3.7 & 2.5 & 2.3 \\
\hline$(Z n)$ & 168.2 & 101.5 & 220.5 & 172.6 & 154.5 & 102.8 & 209.0 & 137.7 \\
\hline
\end{tabular}

After 10 minutes of exposure to the treatment, it can be observed that there was an increase in the salivary concentration of the ions: $\mathrm{Fe}, \mathrm{Ti}, \mathrm{V}, \mathrm{Cr}$ and $\mathrm{Zn}$ and a decrease in: $\mathrm{Al}, \mathrm{Co}, \mathrm{Cu}$, and $\mathrm{Ni}$.

At 7 days after miniscrew insertion, there was a quantitative increase of $\mathrm{Al}, \mathrm{Co}, \mathrm{Cr}, \mathrm{Cu}, \mathrm{Ni}, \mathrm{Ti}$ and $\mathrm{V}$.

At 30 days after insertion, there was a quantitative increase in the salivary concentration $(\mu \mathrm{g} / \mathrm{L})$ of: $\mathrm{Cu}, \mathrm{Ti}, \mathrm{V}$,
$\mathrm{Zn}$ and a quantitative decrease in the salivary concentration of: $\mathrm{Al}, \mathrm{Co}, \mathrm{Cr}, \mathrm{Fe}, \mathrm{Ni}$, when compared with concentrations found before insertion. However, there were no statistically significant differences in the salivary ion concentrations at any of the times studied.

Figure 1 display the amount of metal ions released at each time point.
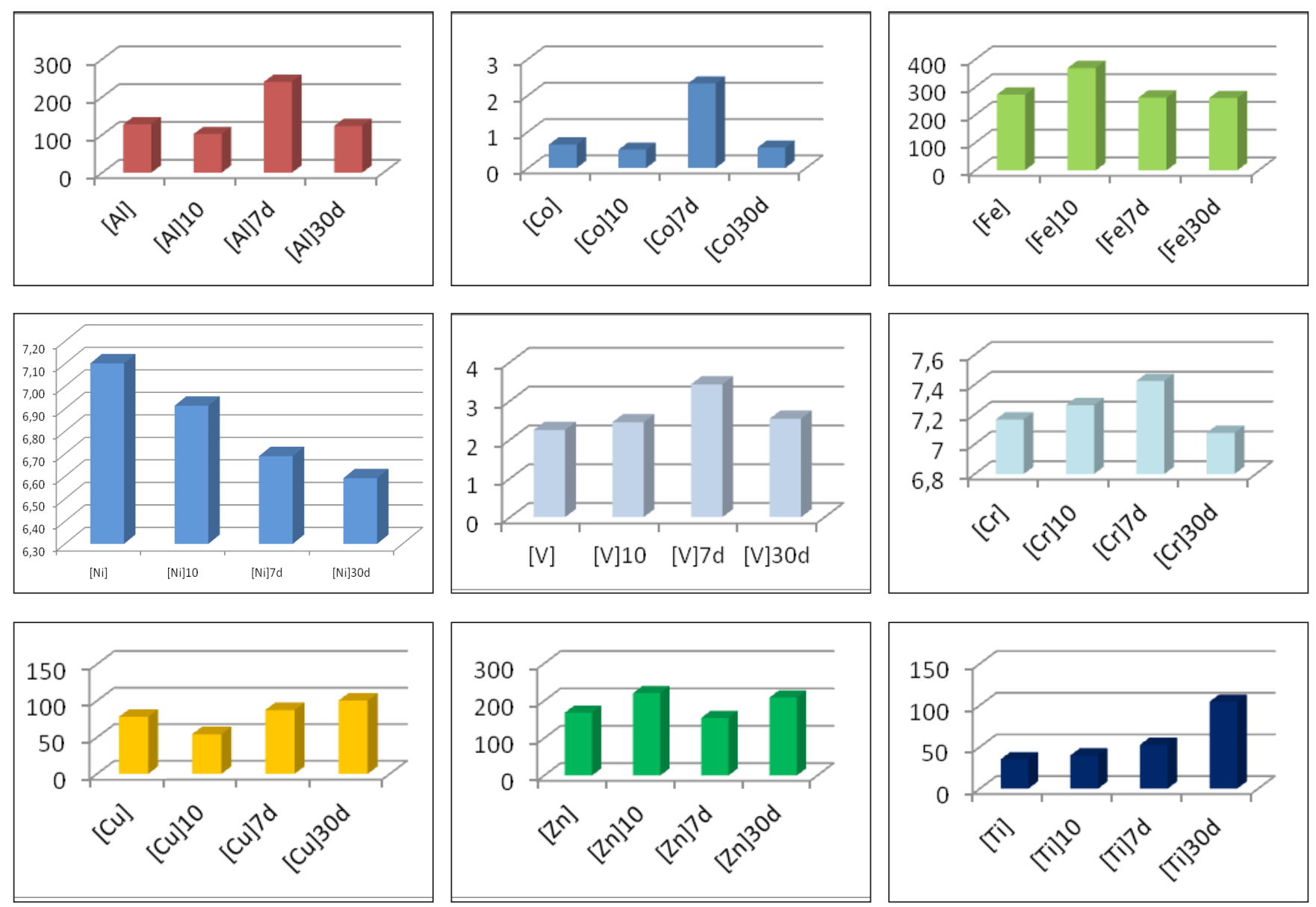

Fig. 1. Release of $\mathrm{Al}, \mathrm{Co}, \mathrm{Fe}, \mathrm{Ni}, \mathrm{V}, \mathrm{Cr}, \mathrm{Cu}, \mathrm{Mn}$, Ti and $\mathrm{Zn}$ ions at different time points $(\mu \mathrm{g} / \mathrm{L})$. 


\section{Discussion}

This study investigates the release of metal ions from fixed orthodontic appliances, particularly with the use of miniscrews as orthodontic anchorage.

The main advantage of the present in vivo study is that the concentrations of salivary metals ions were recorded in the natural oral environment of the patient where actual adverse effects of increased metal concentrations take place. So, this study was carried out to investigate the metal ion concentrations in saliva of patients with fixed orthodontic appliances (20 brackets, 8 bands and wires) and one miniscrew.

The average number of brackets used in a study depends upon whether the patients are treated using an extraction or nonextraction approach and whether the brackets are only placed on a single arch or on both arches. In this study the patients were treated without extraction of pre-molars, brackets are placed on both arches, and the fixed orthodontic appliances were produced by the same manufacturer, in order to avoid additional variables in the study.

Thus, a systemic toxic effect from orthodontic appliances is highly unlikely. However, even such small quantities of metal ions can cause allergic reactions, especially because fixed orthodontic appliances remain in the oral cavity for a long period of time ( 2 to 3 years approximately). For an allergic reaction to occur in the oral mucous membrane, the antigenic potential has to be 5 to 12 times stronger than that on the skin surface. However, various clinical manifestations of hypersensitive reactions to fixed orthodontic appliances have been reported $(19,20)$. Moreover, it was reported that nickel ions released from dental alloys can accumulate in the cells over time, and this may have multiple harmful effects on cells (21). A number of studies have been carried out on the biocompatibility of orthodontic materials, with the aim of determining a limit of biological tolerance and assessing whether the ions released from such materials are within these limits.

In relation to the Ti-6Al-4V alloy components from miniscrew ( $\mathrm{Ti}, \mathrm{Al}$ and $\mathrm{V})$, it was found that $\mathrm{Ti}$ was increased at all time points (T1/T2/T3/T4); $\mathrm{Al}$ was decreased from $\mathrm{T} 1$ to $\mathrm{T} 2$, increased from $\mathrm{T} 2$ to $\mathrm{T} 3$ and decreased from $\mathrm{T} 3$ to $\mathrm{T} 4$; V increased from $\mathrm{T} 1$ to $\mathrm{T} 2$ and from $\mathrm{T} 2$ to $\mathrm{T} 3$, while from T3 to T4 it decreased, though these differences were not statistically significant. While there were no statistically significant differences, it is important to note that the quantitative increase for Ti was observed at all time points, which may be explained by the fact that it is the element with the greatest concentration in the alloy and because of the formation of a superficial titanium oxide layer.

$\mathrm{Al}$ and $\mathrm{V}$ presented a slight increase at 7 days after miniscrew insertion, which may be due to the fact that $\mathrm{V}$ is not present in the superficial oxide layer of Ti-6Al-4V (10) and $\mathrm{Ti}$ and $\mathrm{Al}$ are the metal ions most likely to be released from the Ti-6Al-4V surface (12). There was a higher Ni value in T1 than T2, T3 and T4. However it cannot be affirmed that this value was due to the release of $\mathrm{Ni}$ from the orthodontic appliance, as it had been inside the mouth for a period of approximately 6 to 8 months. Nor could it be attributed to the orthodontic wire, as all patients had stainless steel wires.

There was a minimal difference in the $\mathrm{V}$ concentration at the different time points measured, which would not incur in an alarming situation, especially because the remain in the intraoral environment for a limited time. Our results are in accordance with those found by Morais et al., 2007 (9), who detected varying quantities of $\mathrm{Ti}, \mathrm{Al}$ and $\mathrm{V}$, proving that metal ions were released by Ti-6Al-4V orthodontic miniscrews. However, the authors observed extremely low quantities of these metal ions. Based on the findings of this study, it can by asserted that the quantity of metal ions release is not proportional to the metal content in the alloy, which corroborates with the findings of other studies $(19,20)$.

The method of saliva sampling, processing, and analysis also adds to the variability of the results. Several methods have been suggested to collect resting and stimulated whole saliva $(22,23)$. Most commonly, saliva is collected by draining or spitting into a tube (23). This was done in our study as in previous studies (24). Standardization of saliva collections is important when saliva is used as research material, since saliva composition varies greatly both intraand inter-individually (18). Although the ICP-MS and ICPOES used in this study is a time-consuming and expensive technique, it is highly sensitive, accurate and capable of the determination of a range of metals and several non-metals at concentrations below one part in 10 (12).

Saliva contains acids arising from the degradation and decomposition of food, which increases the corrosion potential of stainless steel and Ti-6Al-4V. In the oral cavity, the bracket-archwire ligation induces "fretting corrosion" of metal surfaces of both the bracket and archwire, as both are moving elements. The presence of complex intraoral flora and accumulation of plaque and its byproducts also add to this variation (18). Moreover, according to Edgar and O' Mullane (25), hormones, drugs, and various diseases also influence saliva composition. In our study, we aimed to exclude patients who presented any systemic disturbance in order to reduce the number of variables that could alter the results.

In summary, metals are present in the saliva of patients with metal brackets, bands and miniscrews depending on a number of variables. The metal contents differed, though not significantly, between consecutive samples per individual. No data are available for a safe limit to metal exposure in saliva. More studies are necessary, especially to investigate the amount of metal ions release when two or more miniscrews are utilized as orthodontic anchorage.

\section{Conclusions}

Based on the findings of this study, it can be concluded that:

1. Orthodontic appliances and miniscrews released metal ions, but in a quantity not proportional to the metal concentration in these materials. 
2. There was no significant difference in the metal ion concentration among the different time points after miniscrew placement.
3. The placement of miniscrew leads to an increase of salivary titanium ion concentrations that is not statistically significant at all periods of saliva collection.
References
1. Morais LS, Serra GS, Muller CA, Palermo EFA, Andrade LR, Meyers MA, Elias CN. In vivo metal ion release from Ti-6Al-4V orthodontic mini-implants. Rev Mater 2007;12:290-7.

2. Ichinose S, Muneta, T, Sekiya I, Itoh S, Aoki H, Tagami M. The study of metal ion release and citotoxicity in Co-Cr-Mo and Ti-Al-V alloy in total knee prosthesis-scanning electron microscopic observation. J Mat Science: Materials in Medicine 2003; 14:79-86.

3. Metikos-Hukovic M, Kwokal A, Piliac J. The influence of niobium and vanadium on passivity of titanium-based implants in physiological solution. Biomaterials 2003;24:3765-75.

4. Evans EJ. Cell damage in vitro following direct contact with fine particles of titanium, titanium alloy and cobalt-chrome-molybdenum alloy. Biomaterials 1994;15:713-7.

5. Haynes DR, Rogers SD, Hay S, Pearcy MJ, Howie DW. The differences in toxicity and release of bone-resorbing mediators induced by titanium and cobalt-chromium-alloy wear particles. J Bone Joint Surgery 1993;75:825-34.

6. Jacobs JJ, Skipor AK, Black J, Urban RM, Galante JO. Release and excretion of metal in patients who have a total hip-replacement component made of titanium-base alloy. J Bone Joint Surg 1991;73A:1475-86.

7. Dobbs HS, Minski MJ. Metal ion release after total hip replacement. Biomaterials 1980;1:193-8.

8. Urban RM, Jacobs JJ, Gilbert JL, Galante JO. Migration of corrosion products from modular hip prostheses. Particle microanalysis and histopathological findings. Ibid 1994; 74:1345-59.

9. Morais LS, Serra GG, Muller CA, Andrade LR, Palermo EF, Elias CN, Meyers M. Titanium alloy mini-implants for orthodontic anchorage: immediate loading and metal ion release. Acta Biomater 2007;3:331-9.

10. Hanawa T. Metal ion release from metal implants. Mat Sci Eng C 2004;24:745-52.

11. Goldberg JR, Gilbert JL. The electrochemical and mechanical behavior of passivated and TiN/AlN-coated CoCrMo and Ti6Al4V alloys. Biomat 2004;25:851-64.

12. Saldaña L, Barranco V, Garcia-Alonso MC, Vallés G, Escudero ML, Munuera L et al. Concentration-dependet effects of titanium and aluminum ions released from termally oxidized Ti6Al4V alloy on human osteoblasts. J Biom Mat Res 2006;77:220-9.

13. Latysh V, Krallics G, Alexandrov I, Fodor A. Application of bulk nanostructured materials in medicine. Current Appl Phys 2006;6:262-6.

14. Sedarat C, Harmand MF, Naji A, Nowzari H. In vivo kinetic evaluation of titanium alloy biodegradation. J Period Res 2001;36:269-74.

15. Liu P, Yao YN, Wu SD, Dong HJ, Feng GC, Yuan XY. The efficacy of deferiprone on tissues aluminum removal and copper, zinc, manganese level in rabbits. J Inorg Bioch 2005;99:1733-7.

16. Heinemann G, Fichtl B, Vogt W. Pharmacokinetics of vanadium in humans after intravenous administration of a vanadium containing albumin solution. Brit J Clin Pharmacol 2003;55:241-45.

17. Barceloux DG. Vanadium. J Toxicol Clin Toxicol 1999;37:265-78.

18. Schipper RG, Silletti E, Vingerhoeds MH. Saliva as research material: biochemical, physicochemical and practical aspects. Arch Oral Biology 2007;52:113-115.

19. Hwang CJ, Shin JS, Cha JY. Metal release from simulated fixed orthodontic appliances. Am J Orthod Dentofacial Orthop 2001;120:383-91.

20. Grimsdottir MR, Gjerdet NR, Hensten-Pettersen A. Composition and in vitro corrosion of orthodontic appliances. Am J Orthod Dentofacial Orthop 1992;101:525-32.

21. Hamano H. Fundamental studies on biological effects of dental metals: nickel dissolution, toxicity and distributions in cultured cells. J Stomatol Soc 1991;59:456-78.

22. Kocadereli I, Atac PA, Kale PS, Ozer D. Salivary nickel and chromiurn in patients with fixed orthodontic appliances. Angle Orthod 2000;70:431-4.

23. Eliades T, Athanasiou AE. In vivo aging of orthodontic alloys: Implications for corrosion potential, nickel release, and biocompatibility. Angle Orthod 2002;72:222-37.

24. Jarvis KE, Gray AL, Houuk RS. Handbook of inductively coupled mass spectrometry. Blackie Academic and professional, London;1996.

25. Edgar WM, O' Mullane DM. Saliva and oral health. 2nd ed., London: British Dental Association; 1996. 